\title{
CREATING PUBLIC INNOVATION THROUGH PUBLIC VALUES (PUBLIC VALUE) CASE STUDY IN EDUCATION DEPARTMENT CITY OF SURABAYA

\author{
Supriyanto
}

Supriyanto $^{5}$, supriyanto-2016@ fisip.unair.ac.id, and supriyanto@uwp.ac.id

This article will examine in depth the concept of public sector innovation, the process of creating public sector innovation and whether it is based on the public value. As a study material the author specializes in innovations created by the Surabaya City Education Office because there are seventeen innovations produced. Most innovations in the public sector are created as a reaction to a crisis when new leaders want to show that they are capable. Consequently the public sector innovation is not able to increase organizational capacity so that innovation tends to be unsustainable. Innovation will stop when the initiator is gone, so visionary leadership and innovation are needed to have compatibility with the system outside of itself and in harmony with relevant regulations and institutions. Innovation will remain sustainable without being influenced by the change of public leadership if it is sourced from public value because public innovations that are created from public values will remain strong to defend and the tendency is increased due to community support.

Keywords: Innovation, Public Sector and Public Value

\section{INTRODUCTION}

In order to improve the competitiveness of the nation, the central and regional governments are required to create public sector innovations. Public sector innovation becomes a necessity in facing the influence of global competition (Dwiyanto, 2017). Through Law Number 23 of 2014 concerning local government, many Ministry/Institution programs encourage and promote innovation such as the Ministry of Home Affairs through the IGA (Innovative Government Award) and the Ministry of PAN and RB through One Institution One Innovation (Widodo, 2017). The characteristics of a rigid, rigid and status quo public sector system must be able to be disbursed through the transmission of a culture of innovation (Suwarno, 2008). The public sector is still relatively foreign in providing innovation in general (private) sectors (Muhammad, 2006). Innovation in the public sector becomes a necessity and necessity in order to realize bureaucratic reform and competition at the Asean Community level and globalization.

Innovation is considered important for the survival of the organization for several reasons as follows: first reducing costs and increasing productivity, thereby increasing profits and strengthening the organization; second, maintaining competitiveness in the global economy; third, the organization's ability to adapt to environmental changes; fourth, to breathe new life, due to slowing or stagnating markets and as an alternative and facilitating entry into new markets by adding creative organizational culture (Lekhi, 2007). Some of the characteristics of the public sector innovation that must be possessed are first there is a new idea / at least there is a new part; secondly, the innovation idea must be implemented in one sector as happened in South Korea, there is no meaning of innovation without action; third is able to provide added value and benefits to the organization (Dwiyanto (2013).

Local governments in Indonesia are encouraged to be able to create public sector innovations that are able to improve services to a better society and in turn create prosperity for the people in their regions. The government bureaucracy in Indonesia basically has the

${ }^{5}$ Student S3 Program studi Social Sciences of Airlangga University and Lecturer at Wijaya Putra University 
potential to carry out various innovations in the administration of governance and development. The first thing they have to do is to know the innovation ability of the government bureaucracy, through the introduction of a number of dimensions of innovation capabilities which include: (1) vision and strategy; (2) adhering to the basic competencies; (3) strengthening the organization's information and intelligence; (4) market and customer orientation; (5) management of ideas and creativity; (6) system and organizational structure; and (7) technology management. Understanding the capabilities of these innovations will help the government bureaucracy to innovate. However, the ability of this innovation will not automatically produce innovation. The innovation of the new government bureaucracy will occur if the innovation capability is placed in three domains which are the drivers and enablers of regional government innovation capabilities: sustainable development, e-government, and new product development.

Bureaucracy in the Surabaya City Government is encouraged for every agency and agency to compete to create public innovation in order to provide easy, fast and quality public services. Based on the results of the public innovation competition organized by the Ministry of MENPAN RB starting in 2015 the Surabaya City Government received many awards and appreciation as one of the nominations including: Media center; Raport Online; Government resources management system (GRMS); Surabaya Single Windows (SSW); e-musrenbang. In the education sector, the Surabaya City Government has succeeded in placing a number of superior public service applications in several categories, namely "Penerimaan Peserta Didik Baru" (PPDB) online. Based on data from the Surabaya City Education Office, it has succeeded in creating 17 (seventeen) educational innovations. The innovation is expected to be able to improve the quality of education in Surabaya citizens.

The success of the Surabaya City education service in creating public innovations raises questions that underline how these innovations were created and whether they are derived from the public values of the people of Surabaya. Many innovations in the public sector occur randomly in reaction to crises or scandals, when new leaders want to show that they are able to manage public organizations (Amadam, 2014). While the issue of innovation in the public sector does not increase the capacity to engage in sustainable innovation. Furthermore, according to Widodo (2017), innovation will stop when the initiator is no longer available, so visionary leadership and innovation are needed to have compatibility with the system outside himself and in harmony with the rules and relevant agencies.

\section{DISCUSSION}

\section{Public Sector Innovation}

Innovation is a relatively new concept in the public administration literature. David Mars research results (in Asrofi, 2008) as for classical literature which contains the concept of innovation in the context of reform, among others, is the article "Innovation in Bureaucratic Institutions" written by Alfred Diamant published in the Public Administration Review (PAR) journal in 1967. In addition, is a book by Caiden entitled "Administrative Reform", published in 1969. In his book, Caiden describes innovation as part of administrative reform (administrative reform). Some of these writings mark the beginning of attention to innovation by public administration experts. However, the concept of innovation is still not popular enough in the realm of public administration and administrative reform. Popular innovations in this field have only been in the last decade.

The lack of popularity of the concept of innovation in the past can be understood because the character of reform is based more on the principles of the Weber bureaucracy. In Weber's conception, bureaucracy requires clear rules, hierarchy, specialization and a relatively 
stable environment. In this context, innovation is seen as not much needed for government bureaucratic apparatus (Kelman, 2005). The obligation of the government bureaucratic apparatus is to carry out the rules that have been established (rule driven). If later innovation is carried out, only in a small intensity and carried out is limited to the level of the top leadership. Innovation, in this case as administrative reform is approached through a top down mechanism (Caiden, 1969).

In the 90's, new public management (NPM) began to shift the hegemony of Weber's conception of administrative reform. The reforms then experienced a shift towards the bureaucracy that prioritized results, participation, customer-oriented, mission-driven, and decentralized (Osborne, 1992). In this new era, innovation was greatly appreciated by supporters of the reform movement. Innovation is generally understood in the context of behavioral change. Innovation is closely related to an environment that is characterized by dynamic and developing (Suwarno, 2013).

Rogers (2003) said that innovation is an idea, practice or object that is considered new by another individual unit. Innovation involves changes in thinking, products, processes and organizations. Change is counted as innovation when they are new to the implementer, but not necessarily new to other businesses (Nelson and Rosenberg, 1993). According to Damanpour in Suwarno (2013) explains that an innovation can be in the form of new products or services, production process technology, new structure and administrative systems or new plans for members of the organization. Another opinion says that innovation is an activity that encompasses the whole process of creating and offering good services or goods that are new, better or cheaper than previously available.

According to UNDESA (2006) innovation in the study of public administration can be divided into several types or types, including:

1. Institutional innovations, namely institutional innovations that focus on the renewal of institutions that have been built or create truly new institutions (focus on the renewal of established institutions and / or the creation of new institutions);

2. Organizational innovation, which is organizational innovation related to identifying new management procedures or techniques in Public Administration;

3. Process innovation, namely process innovation which focuses on improving the quality of public service delivery (focusing on the improvement of quality of public service delivery); and

4. Conceptual innovation, namely conceptual innovation directed at the introduction of new forms of government (the introduction of new forms of governance) such as interactive policy-making, engaged governance, people 's budget reforms, horizontal networks.

The concept of innovation in the public sector apparently has not been as popular as in the business or private sector. Whereas innovation studies were developed in line with efforts to maintain and even develop the ability to compete (compete) or competitive advantage of an organization. This ability is considered important to maintain the survival of the organization. In situations of living organizations by relying solely on comparative advantage and at the same time the competition situation is less visible, the concept of innovation is not well developed. The same thing also happens to public organizations that do not worry at all about their survival problems (Muluk, 2008: 37). Most public sector organizations are less challenged because they are in a non-competitive climate and do not even feel problematic in terms of their survival. So it is natural that the concept of innovation is less developed in the public administration sector.

This type of innovation in the public sector can also be seen according to Halvorsen (2005: 5), who shares the typology of innovations in the public sector as follows: 
1. A new or improved service (new service or improved service), such as home health services.

2. Process innovation, for example changes in the process of providing services or products.

3. Administrative innovation, for example the use of new policy instruments as a result of policy changes.

4. System innovation, is a new system or fundamental change of the existing system by establishing a new organization or a new form of cooperation and interaction.

5. Conceptual innovation, is a change in outlook, such as integrated water management or mobility leasing.

6. Radical change of rationality, what is meant is a shift in general view or mental matrix from employees of government agencies.

Halvorsen further explained that innovation itself can be categorized as follows:

1. Incremental innovations and radical innovations. This innovation is related to the level of authenticity (novelty) of innovation itself. Especially in the industrial sector, most innovations are incremental improvements

2. Top-down innovations and bottom-up innovations. This is to explain who is leading the behavior change process. Top-down eating means management or organization or a higher hierarchy, while bottom-up refers to workers or government employees and decision makers at the unit level (mid-level policy makers).

3. Needs led innovations and efficiency-led innovation. The initiated innovation process has solved the problem in order to improve the efficiency of services, products and procedures.

Mulgan and Albury (2003: 3), stated that successful innovation is the creation and implementation of new processes, products, services, and service methods which are the results of real development in efficiency, effectiveness or quality of results. Therefore innovation has evolved far from the initial understanding which only includes innovation in products (products $\&$ services) and processes only. Product or service innovation comes from changes in the shape and design of products or services, while process innovation comes from a continuous quality renewal movement and refers to a combination of organizational changes, procedures and policies needed to innovate.

In addition Windrum (2008: 8) also in his work entitled: Innovation in Public Sector Services: Entrepreneurship, Creativity and Management, revealed the existence of a taxonomy of innovations consisting of six types of innovation. The six public sector innovations according to Windrum are:

a. Service innovation is the introduction of a new service product or an improvement in the quality of an existing service product.

b. Service delivery innovation involves new or altered ways of delivering to clients or otherwise interacting with them, for the purpose of supplying specific public services.

c. Administrative and organizational innovation changes the organizational structures and routines by which front office staff produces services in a particular way and/or back office staff support front office services.

d. Conceptual innovation is the development of new world views that challenge assumptions that underpin existing service products, processes and organizational. It can occur at all levels and involve the introduction of new missions, new world views, objectives, strategies and rationales.

e. Policy innovations change the thought or behavioural intentions associated with a policy belief system (Sabatier, 1987, 1999). Policy innovations are associated with three types of learning (Glasbergen, 1994). First, there is learning of how policy instruments can be improved to achieve a set of goals. Second, there is conceptual learning that follows changes in shared understanding of a problem and appropriate courses of action. 
Third, there is social learning based on shared understanding of the appropriate roles of policy actors.

f. Systemic innovation involves new or improved ways of interacting withother organizations and knowledge bases. As a consequence of deregulation and increasing competition, partly as the result of budgetary constraints in public administration and the increasing role of service outsourcing.

According to the results of research by Hanna De Vries et. al (2015) types of innovations can be grouped into six groups and can be seen in the Table 1 below:

Table 1

Types of Public Innovation

\begin{tabular}{|c|c|c|c|c|}
\hline No & Type & Focus & Reference & Example \\
\hline 1. & $\begin{array}{l}\text { Innovation } \\
\text { process }\end{array}$ & $\begin{array}{lll}\text { Improved quality } & \text { and } \\
\text { efficiency of internal } & \text { and } \\
\text { external processes } & \end{array}$ & Walker, 2014 & \\
\hline 2. & $\begin{array}{l}\text { Administration } \\
\text { process } \\
\text { innovation }\end{array}$ & $\begin{array}{l}\text { New creation of organizational } \\
\text { forms, introduction of new } \\
\text { management methods and new } \\
\text { working techniques and } \\
\text { methods }\end{array}$ & $\begin{array}{c}\text { Meeus and } \\
\text { Edquist, } 2006\end{array}$ & $\begin{array}{l}\text { Creation of One Stop } \\
\text { Shop by municipalities, } \\
\text { where citizens can } \\
\text { access various services } \\
\text { in one location }\end{array}$ \\
\hline 3. & $\begin{array}{l}\text { Technological } \\
\text { process } \\
\text { innovation }\end{array}$ & $\begin{array}{l}\text { The creation or use of new } \\
\text { technology is permitted in an } \\
\text { organization to provide } \\
\text { services to users and citizens }\end{array}$ & $\begin{array}{l}\text { Edquist et al, } \\
2001\end{array}$ & Digital tax assessment \\
\hline 4. & $\begin{array}{l}\text { Product or } \\
\text { service } \\
\text { innovation }\end{array}$ & $\begin{array}{l}\text { Creation of new services or } \\
\text { products }\end{array}$ & $\begin{array}{l}\text { Damanpour } \\
\text { and Schneider, } \\
2009 \\
\end{array}$ & $\begin{array}{l}\text { Creation of } \\
\text { employment benefits } \\
\text { for disabled youth }\end{array}$ \\
\hline 5. & $\begin{array}{l}\text { Governance } \\
\text { Innovations }\end{array}$ & $\begin{array}{l}\text { Development of new forms } \\
\text { and processes to overcome } \\
\text { certain social problems }\end{array}$ & $\begin{array}{c}\text { Moore and } \\
\text { Hartley, } 2008\end{array}$ & $\begin{array}{l}\text { Government practices } \\
\text { that attempt to improve } \\
\text { self-management and } \\
\text { self-capacity } \\
\text { organizing in } \\
\text { networks }\end{array}$ \\
\hline 6. & $\begin{array}{l}\text { Conceptual } \\
\text { Innovation }\end{array}$ & $\begin{array}{l}\text { The introduction of new } \\
\text { concepts, terms of reference or } \\
\text { new paradigms that help to } \\
\text { reframe the nature of certain } \\
\text { problems and possible } \\
\text { solutions }\end{array}$ & $\begin{array}{l}\text { Bekkers et. al, } \\
2011\end{array}$ & \\
\hline
\end{tabular}

Source: Hanna De Vries et.al 2015

Some public innovations that were successfully created by the Departemen of Education on Surabaya City were 17 (seventeen) innovations as follows : Profile of LKP and PKBM online, PPDB online, Try Out online, Acceptance of online Principals, Visual Student Radio Surabaya, School Financial Management Information System, Private Boss application, school principal acceptance online, online promotion, online salary and mamin online, Non formal education information system, online Report Card, online Journal, Surabaya Learning, Sicakep, P2KGS and $100 \%$ UNBK. 
If the education service innovation is categorized into types of innovation that refers to the opinion of Hanna De Vries et. al (2015) it will enter into several categories, it can be seen in table 2 below:

\begin{tabular}{|c|c|c|}
\hline \multicolumn{3}{|c|}{ Categories Innovation } \\
\hline No & Types & Product Innovation \\
\hline 1 & Innovation process & Acceptance of online Principals \\
\hline 2 & $\begin{array}{l}\text { Administration process } \\
\text { innovation }\end{array}$ & $\begin{array}{l}\text { Online promotion, online salary and mamin } \\
\text { online }\end{array}$ \\
\hline 3 & $\begin{array}{l}\text { Technological process } \\
\text { innovation }\end{array}$ & $\begin{array}{l}\text { Online Report Card, online Journal, Surabaya } \\
\text { Learning, Sicakep, P2KGS, UNBK 100\%, PPDB } \\
\text { online, Non formal education information system }\end{array}$ \\
\hline 4 & $\begin{array}{l}\text { Product or service } \\
\text { innovation }\end{array}$ & $\begin{array}{l}\text { Profile of LKP and PKBM online, Visual Student } \\
\text { Radio Surabaya, PPDB online, Try Out online, } \\
\text { Private Boss application }\end{array}$ \\
\hline 5 & $\begin{array}{l}\text { Governance } \\
\text { Innovations }\end{array}$ & $\begin{array}{llll}\text { School Financial } & \text { Management Information } \\
\text { System } & & & \\
\end{array}$ \\
\hline
\end{tabular}

The educational innovation has been integrated with a system that has been developed by the Surabaya City Government referring to the Government Resources Management System (GRMS). For example, the concrete integration is related to the City Government's policy to provide school operational funds (BOPDA) from the Regional Budget (APBD) so that the management must be accountable and transparent accountable based on the principles of good governance with build a school financial management information system whose supervision can be controlled by the regional representative council (DPRD) of Surabaya city and the Surabaya city government itself.

\section{Public Value}

Public value is a combined view of society about what they consider to be valuable. Public value is describing the value given by an organization to society (Moore, 2009). Public value is what gives a normative consensus about (1) rights, benefits, and prerogative rights that should (and should not) be entitled; (2) the obligation of citizens to society, the state and each other; and (3) must be based on the principles of government policy.

Public value is a combined view of society about what they consider to be valuable. Public value is describing the value given by an organization to society (Moore, 2009). Public value is what gives a normative consensus about (1) rights, benefits, and prerogative rights that should (and should not) be entitled; (2) the obligation of citizens to society, the state and each other; and (3) must be based on the principles of government policy. Public value is the result of an evaluation of how the basic needs of individuals, groups and society as a whole are influenced in relationships involving the community.

The results of the Center for Technology in Government (CTG) 2005 research on public value in the context of government investment in information technology (IT) results show that the government's ability to realize the full value of IT investment is not fully measured in financial results. There are two sources of public value, namely: a. the value resulting from the improvement of the government itself is an asset for the community and $b$. the value resulting from the delivery of specific benefits directly to the person or group.

Jorgensen and Barry B (2007) explained that there were seven structures of the public value universe as follows: 
a. Value related to the contribution of the public sector to the public;

b. Value related to the transformation of interests from decisions

c. Value related to the relationship between public administration and politics

d. Value related between public administration and the environment

e. Value related to intra-organizational

f. Value related to the behavior of public sector employees

g. Value related to general administrative relations with citizens.

Further can be seen in Figure 1:

Figure 1

Structure of the Public Values Universe

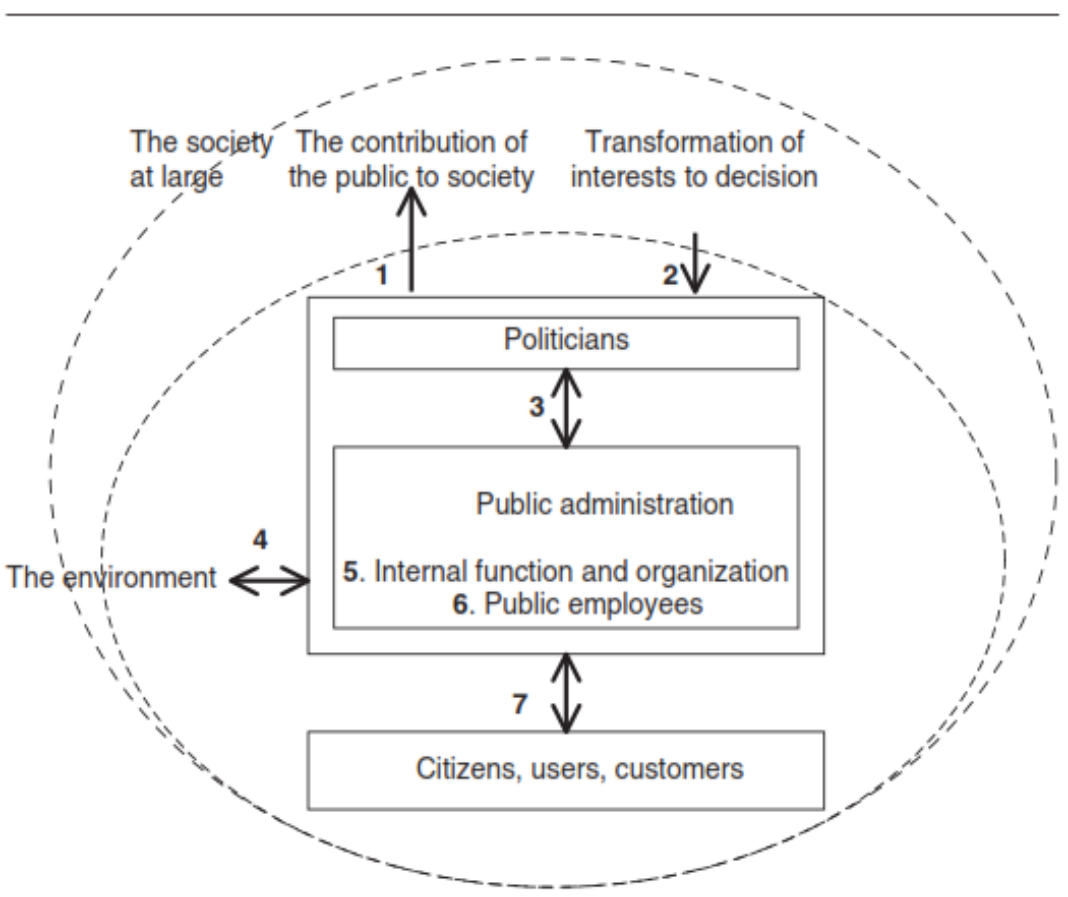

Source: Beck Jørgensen \& Barry Bozeman, 2007

Universal values are interrelated with each other or interrelated with each other in different ways. Three dimensions to be able to consider the value are a). proximity; b). hierarchy c). causality. Proximity values are values that are not bound, neighbor values, covalues or nodal central values. The neighbor's value is important because the first two things help identify more the value used as the starting point, the second the greater the number of neighbor's values, the richer the starting point and the greater the importance of the value. Value with a large number of related and occupying central positions in the value network is called a nodal value. Openness is an attractive nodal value because it has many and varied covalues and is ambiguous (openness really affects some values).

The following can be seen in the Table $\mathbf{3}$ of nodal values according to Beck Jorgensen and Barry Bozeman (2010) : 
Tabel 3

Nodel Value, Neighbor Value and Covalues

\begin{tabular}{|c|c|c|}
\hline Nodal Dignity & Neighbor Value & Co-values \\
\hline Human dignity & $\begin{array}{l}\text { Citizen's self development, citizen } \\
\text { involvement protection the rights } \\
\text { of the individual }\end{array}$ & $\begin{array}{l}\text { Justice, benevolence, voice oh the } \\
\text { future, equity }\end{array}$ \\
\hline Sustainability & Voice of future & $\begin{array}{l}\text { Stability continuity, the common } \\
\text { good, the public interest, moral } \\
\text { standards, ethical, consciousness } \\
\text { solidarity }\end{array}$ \\
\hline Citizen involvement & $\begin{array}{l}\text { The will of the people listening to } \\
\text { public opinion, responsiveness }\end{array}$ & $\begin{array}{l}\text { Dialogue, balancing interests self } \\
\text { development }\end{array}$ \\
\hline Openness & $\begin{array}{l}\text { Responsiveness, listening to } \\
\text { public opinion }\end{array}$ & $\begin{array}{l}\text { Accountability, rule of low, dialogue, } \\
\text { democracy the will of the people } \\
\text { collective choice }\end{array}$ \\
\hline Secrecy & & $\begin{array}{l}\text { Stability continuity, the rule of law, } \\
\text { protection of the rights of the } \\
\text { individual, } \\
\text { effectiveness. }\end{array}$ \\
\hline Compromise & Balancing interests & $\begin{array}{l}\text { Reasonableness, fairness, dialogue, } \\
\text { adaptability, robustness }\end{array}$ \\
\hline Integrity & $\begin{array}{l}\text { Honesty, dignity, fairness, ethical } \\
\text { consciousness, moral standards, } \\
\text { professionalism, } \\
\text { impartiality, loyalty to the regime }\end{array}$ & \\
\hline Robustness & Stability adaptability, relability & Legality, social \\
\hline
\end{tabular}

Source: Torben Beck Jørgensen \& Barry Bozeman, 2010

Educational innovation in the Education Office in the City of Surabaya will continue to develop in a sustainable manner because the innovation was created by the head and all employees of the education office in order to provide quality education services and realize the vision of the education service as an education barometer in Indonesia. In addition, the innovation received political support from members of the DPRD and Surabaya Mayor and financially from the Surabaya City Government.

In addition, there is a huge support from Surabaya citizens and the City education council by giving their participation in making the innovation successful through public dialogue through radio and with hearings that view all stakeholders. The Surabaya community is very concerned and actively participates in supporting the innovations produced by the education office after the seriousness of the Surabaya City Government in improving the quality of education in the City of Surabaya after the Regional Regulation policy that requires 12 years of study. Although there are still obstacles in its implementation, especially in human resources that operate the information system produced. One of the common examples is online report cards, where you still find teachers who have not been able to operate the system due to limited computer skills and frequent internet network problems and difficulties in storage.

\section{Conclusion}

Educational service innovations that have been created by the Surabaya City Education Office will continue to develop sustainably because these innovations are derived from ideas and ideas from within the bureaucracy and in line with the public values of Surabaya city people who are open to positive change, by still giving constructive control through mass media, radio and interactive dialogue. In addition there is support from public officials 
(Mayor) who are very supportive of the innovations developed in line with the integration of the government resources management system (GRMS) program to realize good governance. In addition, the same support is given by the legislative body (DPRD) in order to ensure the education system runs in accordance with the regional regulation agreed upon with the executive.

\section{References}

Asrofi, 2008. Culture of Innovation and Bureaucratic Reform. Journal of Administrative Sciences, Volume V, Number 3, September 2008, p. 246-255

Lekhi, Rohit., 2007. Public Service Innovation., Research Report for the work Fundation's knowledge Economy Programe, Research Republic LLP, Manchester. 